\title{
Distribution of Phrynocephalus helioscopus (Pallas, 1771) (Agamidae, Reptilia) in the West Kazakhstan and Atyrau regions of the Republic of Kazakhstan
}

\author{
K. M. Akhmedenov ${ }^{1 凶}$, A. G. Bakiev ${ }^{2}$, U. S. Mukhambetova ${ }^{1}$ \\ ${ }^{1}$ Makhambet Utemisov West Kazakhstan University \\ 162 N. Nazarbayev Avenue, Uralsk city 090000, Kazakhstan \\ ${ }^{2}$ Samara Federal Research Center of RAS, \\ Institute of Ecology of the Volga River Basin of Russian Academy of Sciences \\ 10 Komzina St., Togliatti 445003, Russia
}

\section{Article info \\ Original Article \\ https://doi.org/10.18500/1814-6090-2021-21- 3-4-91-100}

Received 13 September 2021, revised 26 October 2021 , accepted 28 October 2021

\begin{abstract}
Based on the results of our 2017-2021 field research, the coordinates of 17 meeting points of the sunwatcher toadhead agama (Phrynocephalus helioscopus) (Pallas, 1771) in the West Kazakhstan and Atyrau regions of the Republic of Kazakhstan are given, from $49^{\circ} 17.256^{\prime} \mathrm{N}, 48^{\circ} 14.048^{\prime} \mathrm{E}$ in the North to $46^{\circ} 34.330^{\prime} \mathrm{N}, 55^{\circ} 49.319^{\prime} \mathrm{E}$ in the South. The northern limit of the modern distribution in the Volga-Ural (Volga-Zhaiyk) interfluve is the saline in the Aral-sor lacustrine-saline depression and the Baigutta sor-liman depression in the left bank of the Ural (Zhaiyk) River. The sunwatcher toadhead agama habitats are confined to open spaces with salt lakes and sors. The dependence of the body's upper side colour of sunwatcher toadhead agamas on the general background of the substrate is illustrated, namely: the colour is brown or dark grey on dark substrates, and light grey or ashy on light substrates. The history of the description of the species by P. S. Pallas and I. I. Lepekhin is briefly considered. According to the original and literary data the modern north-western border of the habitat, passing through the West Kazakhstan and the adjacent regions of the Russian Federation, has been clarified. It goes from the northern coast of the Caspian Sea, through Makhambet district of the Atyrau region, Krasnoyarsk and Kharabalinsky districts of the Astrakhan region, Kurmangazinsky district of the Atyrau region, Akhtubinsky district of the Astrakhan region, Bokeyordinsky district of the West Kazakhstan region, Pallasovsky district of the Volgograd region, and Kaztalovsky and Akzhayik districts of the West Kazakhstan region.
\end{abstract}

Keywords: Phrynocephalus helioscopus helioscopus, area, Western Kazakhstan, stations, new finds

For citation: Akhmedenov K. M., Bakiev A. G., Mukhambetova U. S. Distribution of Phrynocephalus helioscopus (Pallas, 1771) (Agamidae, Reptilia) in the West Kazakhstan and Atyrau regions of the Republic of Kazakhstan. Current Studies in Herpetology, 2021, vol. 21, iss. 3-4, pp. 91-100 (in Russian). https://doi.org/10.18500/1814-6090-2021-21-3-4-91-100
This is an open access article distributed under the terms of Creative Commons Attribution 4.0 International License (CC-BY 4.0)
Book of the Astrakhan Region. Astrakhan', Izdatel'skii dom “Astrakhanskii universitet”, 2014, pp. 263-264 (in Russian).

Bozhansky A. T., Polynova G. V. Preliminary results of herpetological zoning of the sandy deserts of the Astrakhan region. In: First Conference of Herpetologists of the Volga Region: Abstracts. Togliatti, Institut ekologii Volzhskogo basseina RAN Publ., 1995, pp. 5-7 (in Russian).

Brushko Z. K. Lizards of Deserts Regions of Kazakhstan. Almaty, Konzhyk Publ., 1995. 228 p. (in Russian).

Bykov A. V., Lindeman G. V., Lopushkov V. A. Fauna of mammals, birds, reptiles, and amphibians of clayey semidesert in Transvolga region. In: Animals of Clayey Semidesert in Transvolga Region (Fauna Conspecta and Ecological Characteristics). Moscow, KMK Scientific Press, 2009, pp. 13-61 (in Russian).

\footnotetext{
${ }^{\square}$ Corresponding author. Department of Geography, Makhambet Utemisov West Kazakhstan University, Kazakhstan.

ORCID and e-mail addresses: Kazhmurat M. Akhmedenov: https://orcid.org/0000-0001-7294-0913, kazhmurat78@mail.ru; Andrey G. Bakiev: https://orcid.org/0000-0002-0338-2740, herpetology@list.ru; Ukiliay S. Mukhambetova: 19.ukyw.98@bk.ru.
} 
Debelo P. V., Chibilyov A. A. Amfibii i reptilii Uralo-Kaspiyskogo regiona [Amphibians and Reptiles of the Ural-Caspian Region]. Yekaterinburg, RIO UrO RAN Publ., 2013. 400 p. (in Russian).

Doskach A.G. Prirodnoe raionirovanie Prikaspiiskoi polupustyni [Natural Zoning of Caspian Semi-desert]. Moscow, Nauka Publ., 1979. 146 p. (in Russian).

Dunaev E. A., Orlova V. F. Zemnovodnye i presmykayushchiesya Rossii: Atlas-opredelitel' [Amphibians and Reptiles of Russia: Atlas-Determinant]. Moscow, Fiton XXI Publ., 2017, 328 p. (in Russian).

Kosareva N. Reptiles of the south of the Stalingrad region (Preliminary message). Scientific Notes of the Stalingrad State Pedagogical Institute A. S. Serafimovich, 1950, iss. 2, pp. 227-240 (in Russian).

Lavrenko E. M. Provincial division of the Black Sea-Kazakhstan subregion of the steppe region of Eurasia. Botanicheskii Zhurnal, 1970, vol. 55, no. 12, pp. 609625 (in Russian).

Lepekhin I. I. The Travel Notes of the Doctor and the Academy of Sciences Adjunct Ivan Lepekhin in Various provinces of the Russian State in 1768 and 1769. St. Petersburg, Imperatorskaia Akademiia nauk Publ., 1771. 538 p. (in Russian).

Natsional'nyi atlas Respubliki Kazakhstan. Pod red. A. R. Medeu. T. 1. Prirodnye usloviia i resursy [A. R. Medeu, ed. National Atlas of the Republic of Kazakhstan. Vol. 1. Natural Conditions and Resources]. Almaty, Institut geografii Publ., 2010. 506 p. (in Russian).

Neruchev V. V., Vasiliev N. F. The fauna of reptiles (Reptilia) of the North-Eastern Caspian Sea. Vestnik zoologii, 1978, no. 6, pp. 36-41 (in Russian).

Nikolsky A. M. Reptiles and Amphibians of the Russian Empire (Herpetologia Rossica). Memoires de L'Academie Imperiale des Sciences de St.-Petersbourg, VIII Serie, Classe Physico-Mathematique, 1905, vol. XVII, no. 1, pp. 1-518 p. (in Russian).

Nikolsky A. M. Faune de la Russie et des Pays Limitrophes Fondee Principalement sur les Collctions Musee Zoologique de L'Academie Imperiale des Sciences de Petrograd. Reptiles (Reptilia). Vol. I. Chelonia et Sauria. Petrograd, Tipografiia Imperatorskoi Akademii Nauk, 1915. 534 p. (in Russian).

Orlova V. F., Semenov D. V. Priroda Rossii: zhizn' zhivotnykh. Zemnovodnye i presmykaiushchiesia [Nature of Russia: Animal Life. Amphibians and Reptiles]. Moscow, Izdatel'stvo AST, 1999. 480 p. (in Russian).

Paraskiv K. P. Presmykaiushchiesia Kazakhstana [The Reptiles of Kazakhstan]. Alma-Ata, AN KazSSR Publ., 1956. 228 p. (in Russian).

Paraskiv K. P., Butovsky P. M. On the fauna of amphibians and reptiles of Western Kazakhstan. Proceedings of the Institute of Zoology of the Academy of Sciences of the Kazakh SSR, 1960, vol. 13, pp. 148-159 (in Russian).
Rachkovskaya E. I., Safronova I. N. The new map of botanical-geographic subdivision of Kazakhstan and Middle Asia within the limits of the desert region. Geobotanical Mapping 1992. St. Petersburg, Nauka Publ., 1994, pp. 33-49 (in Russian).

Sarayev F. A., Pestov M. V. To the Cadastre of Reptiles of the Northern and Northeast Caspian Sea. In: Herpetological Studies in Kazakhstan and Neighboring Countries. Alamaty, ASBK - SOPK Publ., 2010, pp. 174193 (in Russian).

Terentyev P. V., Chernov S. A. Opredelitel zemnovodnykh i presmykayushchikhsya [The Determinant of Amphibians and Reptiles]. Moscow, Sovetskaya nauka Publ., 1949. 340 p. (in Russian).

Khodashova K. S. Prirodnaya sreda $i$ zhivotnyy mir glinistykh polupustyn' Zavolzh'ya. [Natural Environment and Fauna of the Clay Semi-deserts of the TransVolga Region]. Moscow, Leningrad, Izdatel'stvo AN SSSR, 1960. 131 p. (in Russian).

Chernobay V. F. Amphibians, reptiles and animals of the Eltonsky Natural Park. In: Bioraznoobrazie i problemy prirodopol'zovaniia v Priel'ton'e. Otv. red. V. F. Chernobay [V. F Chernobay, ed. Biodiversity and Nature Management Problems in Prieltonye]. Volgograd, PrinTerra Publ., 2006, pp. 47-59 (in Russian).

Chernov S. A. Ecological-faunistic review of reptiles in the south of the Volga - Ural interfluve. Proceedings of the Zoological Institute of the Academy of Sciences of the USSR, 1954, vol. XVI, pp. 137-158 (in Russian).

Chibilev A. A., Debelo P. V. Landshafty UraloKaspijskogo regiona [Landscapes of the Ural-Caspian Region]. Orenburg, Pechatnyi Dom “Dimur", 2006. 288 p. (in Russian).

Shibanov N. V. Materials for the fauna of reptiles of Dagestan. Proceedings of the State Zoological Museum of Moscow State University, 1935, iss. 2, pp. 63-68 (in Russian).

Ananjeva N. B., Tuniyev B., Aghasyan A., Orlov N. L., Tuniyev S., Anderson S., Dujsebayeva T., Terbish K., Melnikov D., Nazarov R., Shestopal A., Litvinchuk S., Shi L., Guo X. Phrynocephalus helioscopus. The IUCN Red List of Threatened Species 2019, 2019, article number e.T48835941A48679076. https://dx.doi.org/ 10.2305/IUCN.UK.2019-2.RLTS.T48835-941A48679076.en

Gmelin J. F. Caroli a Linné Systema Naturae. Ed. 13. T. I, Pars III. Lipsiae, G. E. Beer, 1789, pp. 1033-2224.

Mertens R., Müller L. Liste der Amphibian und Reptilien Europas. Abhandlungen der Senckenbergischen Naturforschenden Gesellschaft, 1928, Bd. 41, Heft 1, S. 1-62.

Pallas P. S. Reise durch verschiedene Provinzen des Russischen Reichs. Erster Teil. St. Petersburg, Gedruckt bey der Kaiserlichen Academie der Wissenschaften, 1771. $504 \mathrm{~S}$. 